\title{
HANNOVER RADIOCARBON MEASUREMENTS IV
}

\author{
M. A. GEYH \\ Niedersächsisches Landesamt für Bodenforschung, \\ Hannover, Germany \\ INTRODUCTION
}

This date list covers a selection of $\mathrm{C}^{1+}$ results of archaeologic, hydrologic and speleologic samples that have been investigated in the period from March 1963 until July 1966. Dates of geologic samples will be presented in the following list.

The ages were calculated on a $\mathrm{C}^{14}$ half-life of $5568 \mathrm{yr}$ and 0.95 of the activity of the NBS oxalic-acid standard, and are quoted in the years before 1950. The age errors encompass the "true $\mathrm{C}^{14}$ ages" with a probability of $68 \%$. Included in the error calculations are the standard deviations of the background and of the NBS standard, which are each $3 \%$, and the counting error of sample. $\mathrm{C}^{13}$ corrections have not been carried out. Infinite ages are stated on a criterion of $2 \sigma$ above background.

The recent activity of water and calcareous sinter is assumed to be $85 \%$ modern. According to the model for age determination of water (Münnich, 1957; Münnich and Vogel, 1959) the $\delta \mathrm{C}^{13}$ value of the precipitated free and fixed carbonic acid (Pearson, 1965; Geyh and Wendt, 1965) would be given by the equation:

$$
\delta \mathrm{C}^{13}{ }_{\mathrm{M}}=\frac{1 / 2\left[\mathrm{HCO}_{3}\right]+\left[\mathrm{CO}_{2}\right]}{\left[\mathrm{HCO}_{3}\right]+\left[\mathrm{CO}_{2}\right]} \delta \mathrm{C}^{13}{ }_{\text {org }}
$$

$\left[\mathrm{HCO}_{3}\right]$ and $\left[\mathrm{CO}_{2}\right]$ are the concentrations of the fixed and free carbonic acid in $\mathrm{mM} / \mathrm{L}$, and $\delta \mathrm{C}^{13}$ org is the $\mathrm{C}^{13}$-ratio of organic material, approximately equal to $-25 \%$. Owing to the low precision of $\mathrm{CO}_{2}$ and $\mathrm{HCO}_{3}$ determinations, $\delta \mathrm{C}^{13}{ }_{\mathrm{M}}$ can only be determined with an error of $\pm 2 \%$. By comparison of the measured $\delta \mathrm{C}^{13}$ value of the precipitated free and fixed carbonic acid from a sample, with $\delta \mathrm{C}^{13}{ }_{\mathrm{x}}$, it can be checked whether carbon dioxide other than that which is biogenic and recent contributed to the carbonic acid equilibrium.

The method is essentially the same as that used for the work described in the previous lists (Hannover I, II, III). For the preparation of the counting gases $\mathrm{C}_{2} \mathrm{H}_{2}$ and $\mathrm{C}_{2} \mathrm{H}_{6}$, a new apparatus was constructed, by help of which one technician can prepare four samples per day.

After extensive general tests, five new counters were set in operation with the result that the number of samples to be dated per year could be increased to 600 . Technical data of these counters are covered in the following table: 


\begin{tabular}{|c|c|c|c|c|c|c|c|c|}
\hline Name & Type & $\begin{array}{c}\text { Vol } \\
\text { L }\end{array}$ & $\mathrm{p}$ & $\begin{array}{c}\mathrm{n}_{0} \\
\mathrm{cpm}\end{array}$ & $\begin{array}{c}\mathrm{n}_{\mathrm{s}} \\
\mathrm{cpm}\end{array}$ & $\begin{array}{l}\operatorname{Age}_{\max } \\
\mathrm{yr}\end{array}$ & $\begin{array}{l}\text { Time } \\
\text { hr }\end{array}$ & Ref. \\
\hline \multirow[t]{2}{*}{ GZR } & Oeschger & 4.57 & 1 & 4.26 & 48.75 & 50,500 & $2 \times 20$ & Geyh, 1965a \\
\hline & & & 3 & 7.75 & 146.00 & 62,000 & $7 \times 24$ & $\begin{array}{l}\text { Houtermans \& } \\
\text { Oeschger, } 1958\end{array}$ \\
\hline BZR & & 1.50 & 1 & 1.52 & 17.30 & 46,000 & $2 \times 20$ & \\
\hline PZR & & 1.50 & 1 & 1.22 & 16.84 & 46,000 & $2 \times 20$ & \\
\hline MZR & $\begin{array}{l}\text { Ciopper } \\
\text { quartz }\end{array}$ & 0.87 & 1 & 1.69 & 7.59 & 39,000 & $2 \times 20$ & $\begin{array}{l}\text { de Vries and } \\
\text { others, } 1959\end{array}$ \\
\hline LZR & tube & 0.22 & 1 & 1.05 & 2.32 & 33,000 & $2 \times 20$ & \\
\hline SZR & $\begin{array}{l}\text { Scint. } \\
\text { plastic }\end{array}$ & 0.04 & 1 & 0.15 & 0.30 & 19,000 & $2 \times 20$ & Geyh, 1965a \\
\hline
\end{tabular}

(Abbreviations: $\mathrm{p}=$ filling pressure in atm; $\mathrm{n}_{0}=$ background; $\mathrm{n}_{\mathrm{s}}=.95 \mathrm{x}$ net counting rate of NBS oxalic-acid standard; $\max$ age $_{\max }=$ measured infinite age; time = counting time; Vol is effective volume.)

The measurements are done with a vacuum-tube apparatus tested for its stability, without $\alpha$-discriminator. Each sample is measured twice in different counters. In those cases where the sample sizes are too small for the filling of one counter with $1 \mathrm{~atm}$, background gas is admixed (Geyh, 1966). For checking the constancy of the $\mathrm{C}^{14}$ time-scale, a dendrochronologically dated wood sample was measured monthly. Routine operating conditions are fixed according to methods already described (Geyh, 1965a).

Sample descriptions have been prepared in collaboration with collectors and submitters.

Abbreviations in the following text are: N.L.f.B. for Niedersächsisches Landesamt für Bodenforschung, Hannover (Germany); B.f.B. for Bundesanstalt für Bodenforschung, Hannover (Germany); and G.L. for Geologisches Landesamt.

\section{ACKNOWLEDGMENTS}

The author thanks Erika Guhlich, Renate Eichhorn, Norgart Lutz, and Isa Krell for their excellent work in chemical preparation and measurement of samples. Adolf Schorn and Gerhard Morgenthal constructed the new counting tubes and were responsible for their service. The $\mathrm{C}^{13}$ measurements were carried out by Wolfgang Stahl (B.f.B.) with an Atlas CH4 mass spectrometer. The chemical water analyses were taken over by Heinrich Fauth (B.f.B.). Heinrich Schneekloth (N.L.f.B.) assisted in the selection of samples. 


\section{SAMPLE DESCRIPTIONS}

I. ARCHAEOLOGIC SAMPLES

\section{A. Germany}

\section{Tarmstedt series, Niedersachsen}

Charcoal from excavation of prehistorical circular burial with vault

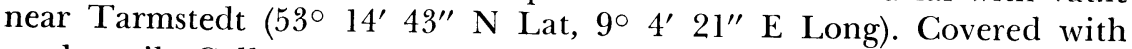
sandy soil. Coll. 1966 and subm. by Joachim Deichmüller, Niedersächsisches Landesverwaltungsamt für Bodendenkmalspflege, Hannover. Samples date a unique grave, presumably of Bronze age.

Hv-1391. Tarmstedt, 0.4 m depth $2800 \pm 85$

Sample of tree coffin.

\section{Hv-1392. Tarmstedt, $0.5 \mathrm{~m}$ depth}

Sample of tree coffin.

Hv-1393. Tarmstedt, $0.3 \mathrm{~m}$ depth $2955 \pm 80$ Wall remains of a vault.

\section{Hv-1395. Tarmstedt, $0.2 \mathrm{~m}$ depth}

Remains of a wooden peg from the vault.

\section{Hv-1396. Tarmstedt, $0.3 \mathrm{~m}$ depth}

Remains of the vault entrance.

\section{Hv-1397. Tarmstedt, $0.8 \mathrm{~m}$ depth}

Remains of a tree coffin. Comment: according to the manner grave arrangement, age of 3500 B.P. was assumed. $\mathrm{C}^{14}$ results show that in $\mathrm{N}$ Germany cremations with circular grave arrangements were performed even later.

\section{Hv-827. Ohlenstedt, Niedersachsen}

Chacoal from excavation of lower grave, 0.2 to $0.3 \mathrm{~m}$ depth, near

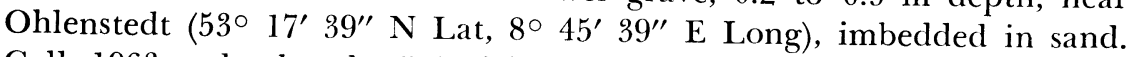
Coll. 1963 and subm. by J. Deichmüller. Comment: according to layout of grave and to ceramics, assignment was to older Bronze age.

\section{Hv-821. Gräpel, Niedersachsen}

Charcoal from excavation of hill grave, $0.2 \mathrm{~m}$ depth, near Grapel

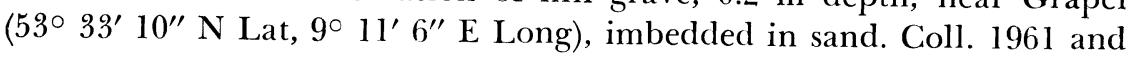


subm. by J. Deichmüller. Comment: agrees with archaeologic dating of a cremation urn.

\section{Hv-366. Billerbeck, Niedersachsen}

$6010 \pm 100$

Charcoal from excavation of hill grave, $0.6 \mathrm{~m}$ depth, near Biller-

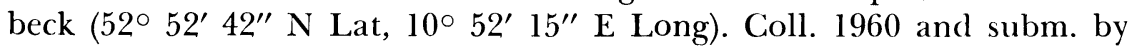
J. Deichmüller. Comment: sample dates an ornamented pottery.

\section{Hv-369. Bullenburg, Niedersachsen}

$4100 \pm 140$

Charcoal from hill grave with circular trench, $1.3 \mathrm{~m}$ depth, near

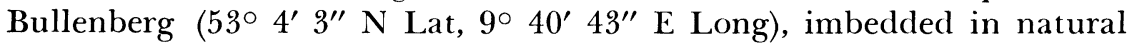
soil. Coll. 1957 and subm. by J. Deichmüller. Comment: sample dates a hill grave type, with a form of burial that so far could not be classified chronologically.

\section{Deinste series, Niedersachsen}

Charcoal from excavation of large stone grave near Deinste $\left(53^{\circ} 30^{\prime}\right.$ $45^{\prime \prime} \mathrm{N}$ Lat, 9० 27' 24" E Long), overlain by natural soil. Coll. 1959 and subm. by J. Deichmüller. Sample date large Neolithic stone grave and ceramics.

\section{Hv-345. Deinste, $1.6 \mathrm{~m}$ depth}

$4170 \pm 80$

Charcoal from fireplace near a vault.

\section{Hv-348. Deinste, $1.4 \mathrm{~m}$ depth}

$4040 \pm 110$

Charcoal from a cult fireplace.

2090 в.C.

\section{Hv-824. Deinste, $1.6 \mathrm{~m}$ depth}

$\mathbf{3 4 7 0} \pm \mathbf{8 0}$

Charcoal from the stone chamber.

\section{Hv-825. Deinste, $1.5 \mathrm{~m}$ depth}

Charcoal from stone settlement beside the main burial place. Comment: in contrast to the archaeologic assumption, i.e. that the stone grave and the cult fireplace are of same age, results prove that stone grave was built during Bronze age.

\section{Goldbeck series, Niedersachsen}

Charcoal from excavation of circular burial with wooden vault near

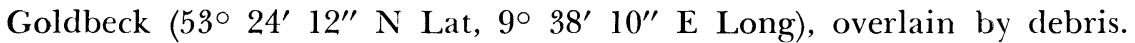
Coll. 1962 and subm. by J. Deichmüller. Sample date Stone age burial place, which was later used for a burial during Bronze age. 
Hv-752. Goldbeck, $0.45 \mathrm{~m}$ depth

Charcoal from upper burial place.

Hv-753. Goldbeck, $0.80 \mathrm{~m}$ depth

Plank of vault.

Hv-759. Goldbeck, $1.30 \mathrm{~m}$ depth

Charcoal from circular trench.

Hv-810. Goldbeck, $1.20 \mathrm{~m}$ depth

Charcoal from the chief burial. Comment: pottery findings of the old burial place date them to 2000 B.c. Discovery of a flint spearhead suggests Bronze age date for younger burial place.

\section{Hv-804. Effeln, Nordrhein-Westfalen}

Charcoal from excavation of urn cemetery of Hallstatt age near Effeln ( $51^{\circ} 32^{\prime} 54^{\prime \prime} \mathrm{N}$ Lat, $8^{\circ} 22^{\prime} 59^{\prime \prime} \mathrm{E}$ Long), overlain by "parabraunerde." Coll. 1964 and subm. by E. von Zezschwitz, G. L. NordrheinWestfalen, Krefeld. Comment: dating of an urn, ornamented with a delicate comb-like line, which according to $\mathrm{H}$. Beck, Landesmuseum für Vor- und Frühgeschichte, Münster, was assigned to Hallstatt D or C (2600 в.P.) (Henneböle, 1959).

\section{Hv-773. Luttum, Niedersachsen}

$3660 \pm 70$ 1710 B.c.

Charcoal of hill grave excavation, $0.9 \mathrm{~m}$ depth, near Luttum $\left(52^{\circ}\right.$ $53^{\prime} 48^{\prime \prime} \mathrm{N}$ Lat, $9^{\circ} 18^{\prime} 18^{\prime \prime} \mathrm{E}$ Long), overlain by sand. Coll. 1964 and subm. by R. Schünemann, Heimatmuseum, Borstel. Comment: dating of a cup, from a single grave, with scratched angular band-decoration; age of 1800 в.c. was assumed (Schünemann, 1965).

\section{Hv-587. Walkemühle, Niedersachsen}

$3420 \pm 60$

Charcoal from excavation of hill burial place of Bronze age, 0.5 to $0.7 \mathrm{~m}$ depth, at Walkemühle (51 $31^{\circ} 31^{\prime} 25^{\prime \prime} \mathrm{N}$ Lat, $9^{\circ} 55^{\prime} 49^{\prime \prime} \mathrm{E}$ Long). Coll. 1963 and subm. by R. Maier, Seminar für Vor- und Frühgeschichte der Universität Göttingen. Comment: according to earlier dates (Meyer and others, 1963) of similar fragments from hill graves, should be Bronze age (approx. 1400 в.c.) or younger (Maier, 1964).

\section{Hv-1394. Tarmstedt, Niedersachsen}

$1440 \pm 75$

\section{A.D. 510}

Charcoal from exposure of an ancient iron smelting plant, 0.5 to 0.7

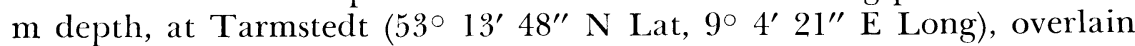
by sand. Coll. 1966 and subm. by J. Deichmüller. Comment: owing to absence of artifacts, no clues for age estimation. 


\section{Isernhagen series, Niedersachsen}

Charcoal from excavation of ancient slag hills, 0.2 to $0.3 \mathrm{~m}$ depth,

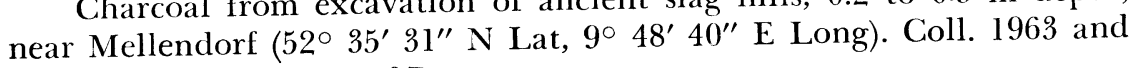
subm. by H. Lang, N.L.f.B.

\section{Hv-523. Isernhagen}

A.D. 1350

\section{Hv-524. Isernhagen}

A.D. 1290

$600 \pm 50$

Comment: samples originate from the time when bog-iron smelting was carried out in Niedersachsen. According to pottery, end of this period is near A.D. 1200 to 1300 (Lang, 1962).

\section{Hv-722. Steinkart, Niederbayern}

$1480 \pm 70$

Charcoal from a hitherto unknown, collapsed mining shaft, $7.7 \mathrm{~m}$

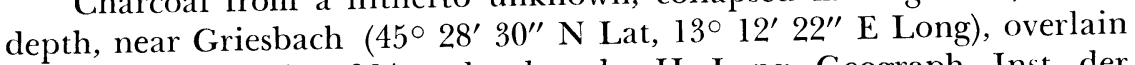
by forest soil. Coll. 1964 and subm. by H. Lang, Geograph. Inst. der Univ., München. Comment: sample dates an old mining site which, according to type of its construction and to quality of the ore, may have been established between 500 B.C. and A.D. 1000.

\section{Dümmer series, NW-Germany}

Samples of Neolithic settlement in vicinity of Dümmer lake at

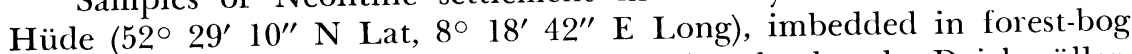
peat, underlain by gyttja. Coll. 1962 to 1964 and subm. by Deichmüller. Samples date the unique Stone age settlement in NW Germany (Deichmüller, 1965a; Deichmüller, 1965b), the excavation of which produced many interesting and unique finds, i.a. a complex foreign ceramics.

\section{Hv-317. Dümmer, $1.2 \mathrm{~m}$ depth}

$\mathbf{5 4 3 0} \pm \mathbf{8 0}$

Wood of house post.

3480 в.C.

\section{Hv-374. Dümmer, $0.7 \mathrm{~m}$ depth}

$5420 \pm 50$

Charcoal; dates an ornamented pottery.

Hv-814. Dümmer, $0.9 \mathrm{~m}$ depth

$5565 \pm 85$

Bearing pile of dwelling.

Hv-816. Dümmer, 0.5 m depth

$5425 \pm 350$

Charcoal from earthen vessel.

3475 B.C.

Hv-1220. Dümmer, 0.7 m depth

$5170 \pm 90$

Wooden bow, presumably from a mill. 
Hv-1230. Dümmer, $0.5 \mathrm{~m}$ depth

Charred food remains on braided pottery.

Hv-349. Dümmer, $0.5 \mathrm{~m}$ depth

Stump of tree that crushed the log canoe.

Hv-373. Dümmer, $0.6 \mathrm{~m}$ depth

Charcoal; dates fragment of braided pottery.

Hv-813. Dümmer, 0.4 m depth

Bark of a house post.

Hv-1221. Dümmer, $0.5 \mathrm{~m}$ depth

Log canoe overlain by tree.

Hv-318. Dümmer, 0.3 m depth

Charcoal from lower habitation layer.

Hv-455. Dümmer, $0.7 \mathrm{~m}$ depth

Charcoal from habitation layer, $7 \mathrm{~m}$ distant from $\mathrm{Hv}-1318$.

\section{Hv-817. Dümmer, 0.4 m depth}

Bearing pile of dwelling.

\section{Hv-819. Dümmer, 0.4 m depth}

Bearing pile of dwelling. Comment: age determinations by means $2840 \pm 95$ 890 B.C.

$2770 \pm 85$ 820 B.C. of stratigraphic and pollen-analytic investigations were difficult owing to unevenness of the terrain. Comparisons of pottery (Knoll, 1959) confirm the $\mathrm{C}^{1+}$ dates. Pollenanalytic investigations by J. Schüttrumpf, Köln, indicate a period around 4500 B.P. (Upper Neolithic). $\mathrm{C}^{14}$ dates provided proof of four phases of settlement and revealed many hitherto unknown relations in the field of Stone-age research of $\mathrm{N}$ Germany.

\section{Wooden plank from excavation of old bridge, 2 to $3 \mathrm{~m}$ depth, near Ottmarsbocholt (51 $53^{\prime} 48^{\prime \prime} \mathrm{N}$ Lat, $7^{\circ} 39^{\prime} 46^{\prime \prime} \mathrm{E}$ Long), overlain by high-flood loam. Coll. 1965 and subm. by H. C. Poeschel, Geograph. Inst. of Univ., Münster. Comment: samples dates bridge over Emmer river which, according to archival studies (Krusch, 1933), existed in A.D. 851.}




\section{Madeburg series, Niedersachsen}

Charcoal from excavation of castle of Madeburg $\left(51^{\circ} 24^{\prime} 19^{\prime \prime} \mathrm{N}\right.$ Lat, $9^{\circ} 56^{\prime} 00^{\prime \prime}$ E Long), overlain by humic soil. Coll. 1964 and subm. by H. G. Peters, Seminar für Früh- und Urgeschichte der Univ., Göttingen.

\section{Hv-707. Madeburg, $1.35 \mathrm{~m}$ depth}

Hv-710. Madeburg, $0.7 \mathrm{~m}$ depth

Hv-711. Madeburg, 0.4 m depth

Hv-712. Madeburg, $0.1 \mathrm{~m}$ depth

Comment: according to fragments of pottery, age of A.D. 900 to 1100 assumed (Peters, 1965).

\section{Hv-586. Rosdorf, Niedersachsen}

Charcoal of settlement midden, 0.3 to $0.9 \mathrm{~m}$ depth, near Rosdorf $\left(51^{\circ} 30^{\prime} 21^{\prime \prime} \mathrm{N} \mathrm{Lat}, 9^{\circ} 54^{\prime} 8^{\prime \prime} \mathrm{E}\right.$ Long), overlain by loess. Coll. 1964 and subm. by H. G. Peters. Comment: according to older line-band ceramics found, age of 4500 to 4400 B.c. assumed (Maier and Peters, 1965; Meyer and others, 1963; Behrens, 1962).

\section{Hv-709. Wittenburg, Niedersachsen}

A.D. 1115

$\mathbf{8 3 5} \pm \mathbf{8 0}$

Charcoal, $0.7 \mathrm{~m}$ depth, from excavation of castle Wittenburg $\left(51^{\circ}\right.$ $36^{\prime} 9^{\prime \prime} \mathrm{N}$ Lat, 9॰ 58' 3" E Long), overlain by shell limestone. Coll. 1964 and subm. by H. G. Peters, Comment: archaeologic dating was not possible because of absence of specimens (Peters, 1965).

\section{Hv-1040. Möllenbeck, Niedersachsen}

$1205 \pm 105$

Charcoal from post, 0.1 to $0.6 \mathrm{~m}$ depth, in foundation of former

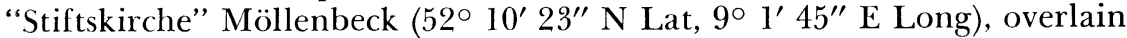
by clay and gravel. Coll. 1965 and subm. by K. Maier, Landeskonservator, Hannover. Comment: older than A.D. 900, according to Carolingian pottery; $\mathrm{C}^{14}$ age proves that the apsides-foundations of the crypt are the oldest unit of the church. Therefore occupancy of this region must have taken place prior to the founding of the monastery (Hentger, 1962; Maier, 1966).

\section{Lengderburg series, Niedersachsen}

Charcoal from trench, $0.4 \mathrm{~m}$ deep, into bulwark of castle Lengderburg (51 $30^{\prime} 29^{\prime \prime} \mathrm{N}$ Lat, $10^{\circ} 3^{\prime} 56^{\prime \prime}$ E Long), overlain by thin humus laver and weathered shell limestone. Coll. 1965 and subm. by H. G. 
Peters. Samples serve to establish different building phases of prehistoric fortresses.

\section{Hv-931. Lengderburg}

$5190 \pm 115$

\section{Hv-932. Lengderburg}

$\mathbf{5 3 0 5} \pm \mathbf{8 5}$

Comment: until now, three phases of castle construction were known in Niedersachen: in the 7th to the 5th century в.c. and in the Middle ages. The new discovery is surprising.

\section{Hedemünden series, Niedersachsen}

Charcoal from rampart near Hedemünden $\left(51^{\circ} 23^{\prime} 52^{\prime \prime} \mathrm{N}\right.$ Lat, $2{ }^{\circ}$ $43^{\prime} 42^{\prime \prime}$ E Long), overlain by humus and loess. Coll. 1965 and subm. by H. G. Peters. Samples date different building phases of a prehistoric fortress.

\section{Hv-928. Hedemünden, $0.3 \mathrm{~m}$ depth}

$2135 \pm 75$

\section{Hv-929. Hedemünden, $0.5 \mathrm{~m}$ depth}

Comment: pottery findings imply age of 100 в.C.

$$
2190 \pm 75
$$

240 B.C.

\section{Hv-567. Seelenhof Ried, Württemberg}

$8075=65$

6125 B.C.

Wood from prehistoric dam, $1.05 \mathrm{~m}$ depth in Seelenhof Ried $\left(48^{\circ}\right.$ $5^{\prime} 2^{\prime \prime} \mathrm{N}$ Lat, $27^{\circ} 15^{\prime} 32^{\prime \prime} \mathrm{E}$ Long), overlain by $0.4 \mathrm{~m}$ humic soil and 0.6 m sand. Coll. 1961 and subm. by K. H. Göttlich, Wasserwirtschaftsamt Sigmaringen, Württemberg. Comment: discovery of Mesolithic tools confirms the $\mathrm{C}^{14}$ dating (Göttlich, 1965). Thus, dam represents one of the oldest manmade trackways in Europe.

\section{Hv-637. Büderich, Nordrhein-Westfalen}

$1525 \pm 80$

Wood from bearing pile of castle, $2 \mathrm{~m}$ depth, near Büderich (51 $16^{\prime} 7^{\prime \prime} \mathrm{N}$ Lat, $6^{\circ} 40^{\prime} 36^{\prime \prime} \mathrm{E}$ Long), overlain by peat. Coll. 1963 and subm. by J. Braun, G. L. Nordrhein-Westfalen, Krefeld. Comment: according to construction as investigated by A. Herrnbroth, Rhein. Landescuseum, Bonn, foundation should originate from ca. A.D. 900.

\section{B. Foreign Countries}

\section{Hv-1098. Lüderitz, SW Africa}

$9960 \pm 390$

8010 B.C.

Bone of rhinoceros from watering place, depth $80 \mathrm{~cm}$, on Lüderitzbucht (26 $46^{\circ} \mathrm{S}$ Lat, $15^{\circ} 14^{\prime} \mathrm{W}$ Long), imbedded in sand. Coll. 1965 and subm. by H. Kazmaier, Lüderitz Mus., Lüderitzbucht. Comment: postglacial watering place of wild animals in the Nambi desert (Heinz, 1933). Contamination of sample is unlikely. 


\section{Hv-556. Embouchure du Loa, Chile}

$1425 \pm 80$

Charcoal from excavation of Indian grave near embouchure $\left(21^{\circ}\right.$ '2-' S Lat, 70 5' W Long). Coll. 1963 and subm. by J. C. Spahni, Genf. Comment: according to pottery fragments of Atacaman culture, 6th to 7 th century A.D. was assumed. Date shows extension of Atacaman culture as far as the Pacific coast (Bennet, 1946; Bird, 1946).

\section{Hv-557. Embouchure du Loa, Chile}

$1735 \pm 100$

Charred human bone from excavation of Indian grave near Embouchure du Loa (21 $27^{\prime} \mathrm{S}$ Lat, $70^{\circ} 5^{\prime} \mathrm{W}$ Long). Coll. 1963 and subm. by J. C. Spahni. Comment: same period as Hv-556.

\section{Hv-298. Tulán, Chile}

$1180 \pm 60$

Charcoal from grotto near Tulán $\left(23^{\circ} 48^{\prime} \mathrm{S}\right.$ Lat, $68^{\circ} 2^{\prime} \mathrm{W}$ Long). Coll. 1962 and subm. by J. C. Spahni. Comment: cave paintings of men and lamas, and also an abundance of geometric symbols, point to time of main Atacaman culture ca. 10th century A.D.

\section{Hv-299. San Lorenzo, Chile}

Charcoal from fireplace in grotto of San Lorenzo $\left(23^{\circ} 15^{\prime} \mathrm{S}\right.$ Lat, $67=25^{\prime}$ W Long). Coll. 1962 and subm. by J. C. Spahni. Comment: cave paintings of hunting ceremony with dancing people point, as does the date, to preceramic phase.

\section{Moquegua series, Peru}

Samples from Indian graves near Chen-Chen $\left(17^{\circ} 11^{\prime} 56^{\prime \prime} \mathrm{S}\right.$ Lat, $70=45^{\prime} 42^{\prime \prime} \mathrm{W}$ Long), imbedded in volcanic ash. Coll. 1965 and subm. by H. D. Disselhoff, Deutsche Forschungsgemeinschaft, Berlin. Dates should prove migration of the Tiahuanaco culture from Bolivian uplands.

Hv-1076. Chen-Chen, $1.5 \mathrm{~m}$ depth

Cotton tissue from stone grave.

\section{Hv-1077. Chen-Chen, $0.9 \mathrm{~m}$ depth}

Charcoal from grave, $70 \mathrm{~m}$ distant from $\mathrm{Hv}-1076$. Comment: according to decorated pottery, approx. A.D. 900.

\section{Toro Grande series, Peru}

Samples from Indian graves near Toro Grande $\left(16^{\circ} 15^{\prime} 16^{\prime \prime} \mathrm{S}\right.$ Lat, $72=29^{\prime} 29^{\prime \prime} \mathrm{W}$ Long), imbedded in volcanic ash. Coll. 1965 and subm. by H. D. Disselhoff. Datings facilitate correlation of styles of ceramics. 
Hv-1078. Toro Grande, $1.0 \mathrm{~m}$

A.D. 955

Wood from exposure.

$$
960 \pm 60
$$

Hv-1079. Toro Grande, $0.6 \mathrm{~m}$ to $1.0 \mathrm{~m}$

A.D. 990

Cotton textiles from exposure, $10 \mathrm{~m}$ distant from $\mathrm{Hv}-1078$. Comment: according to pottery, A.D. 850 was assumed.

\section{Cabezas Achatadas series, Peru}

Samples from Indian graves near Cabezas Achatadas $\left(16^{\circ} 36^{\prime} 00^{\prime \prime} \mathrm{S}\right.$ Lat, $72^{\circ} 45^{\prime} 6^{\prime \prime} \mathrm{W}$ Long), imbedded in sand. Coll. 1965 and subm. by H. J. Disselhoff. Samples serve style classification of textiles.

Hv-1101. Cabezas Achatadas, $1.9 \mathrm{~m}$

Wood sample.

Hv-1155. Cabezas Achatadas, $1.5 \mathrm{~m}$

Rush mat, picked up $7 \mathrm{~m}$ SE of Hv-1101.

Hv-1102. Cabezas Achatadas, $1.8 \mathrm{~m}$
$1805 \pm 85$

A.D. 145

$$
1855 \pm 95
$$

A.D. 95

$$
1530 \pm 70
$$

A.D. 420

Textiles, picked up $7 \mathrm{~m}$ away from $\mathrm{Hv}-1101$. Comment: according to style comparison, possibly 2000 B.P.

\section{Loreto Viejo series, Peru}

Samples from burial places at Loreto Viejo $\left(17^{\circ} 36^{\prime} 50^{\prime \prime} \mathrm{S}\right.$ Lat, $71^{\circ}$ 14' 18" W Long), imbedded in sand. Coll. 1965 by H. J. Disselhoff; subm. by G. S. Vescelius, Am. Mus. of Nat. Hist., New York. Samples date Loreto complex, a derived Tiahuanaco culture, and correlate textile styles.

Hv-1080. Loreto Viejo, $1.0 \mathrm{~m}$ depth

Coca leaves from looted cave.

Hv-1081. Loreto Viejo, surface A.D. 1200
$470 \pm 235$

A.D. 1480

$$
750 \pm 60
$$

A.D. 1200

Hv-1091. Loreto Viejo, $0.7 \mathrm{~m}$ depth

$980 \pm 70$ A.D. 970

Cloth, found $10 \mathrm{~m}$ away from $\mathrm{Hv}-1080$. Comment: according to associated ceramics, ca. A.D. 900 .

\section{Punta Islay series, Peru}

Charcoal from dwelling site, immediately below surface at Punta Islay ( $17^{\circ} 00^{\prime} 41^{\prime \prime} \mathrm{S} \mathrm{Lat,} 72^{\circ} 6^{\prime} 30^{\prime \prime} \mathrm{W}$ Long), overlain by waste layer 
with shells. Coll. 1965 and subm. by G. S. Vescelius. Samples date different phases of Islay culture.

\section{Hv-1087. Punta Islay}

Sample from Stratum I (Level A).

Hv-1082. Punta Islay

Sample from Stratum II (Level B).

\section{Hv-1088. Punta Islay}

Sample from Strata XII to XIII (Level M-N). Comment: according to associated ceramics, samples originate from fairly late, intermediate and early phases of Islay culture or Episode B 5, A 6 and A 2/3 of Punta Islay sequence. Estimated ages 200 B.c., 300 в.c., 600 B.c. No absolute dating was performed before in this area.

\section{Hv-1083. Cueva de Caru, Peru}

$8190 \pm 130$

6240 в.C.

Charcoal from exposure, $1.5 \mathrm{~m}$ depth, at Cueva de Caru $\left(17^{\circ} 27^{\prime}\right.$ $20^{\prime \prime} \mathrm{S}$ Lat, $70^{\circ} 00^{\prime} 30^{\prime \prime} \mathrm{W}$ Long), overlain by sand. Coll. 1965 by $\mathrm{R}$. Ravines; subm. by G. S. Vescelius. Comment: sample serves to date preceramic assemblage with projectile points of Pampa Colorada type.

\section{Puyenca series, Peru}

Charcoal from undisturbed middens, immediately below surface at Puyenca ( $16^{\circ} 13^{\prime} 2^{\prime \prime} \mathrm{S}$ Lat, $73^{\circ} 40^{\prime} 5^{\prime \prime} \mathrm{W}$ Long). Coll. 1965 and subm. by G. S. Vescelius. Dates late preceramic site at Punta Atico.

\section{Hv-1084. Puyenca}

$8070 \pm 145$

Sample from one of outlying middens.

\section{Hv-1086. Puyenca}

6120 в.C.

Sample from one of central middens. Comment: because evidently preceramic, age of 1200 B.c. was assumed.

\section{Hv-1090. Playa Chira, Peru}

$8765 \pm 160$ 6815 B.c.

Carbonaceous soil from shell heap, alt. $55 \mathrm{~m}$ above sealevel, at Playa Chira (16 $31^{\prime} 10^{\prime \prime} \mathrm{S}$ Lat, $72^{\circ} 54^{\prime} 25^{\prime \prime} \mathrm{W}$ Long). Coll. 1965 and subm. by G. S. Vescelius. Comment: preceramic culture, estimated age 2250 B.c.

\section{Hv-1089. Puyenca II, Peru}

$730 \pm 90$

Charcoal from Stratum IV (Level B) of large dwelling site at Puyenca (16 $16^{\prime} 40^{\prime \prime} \mathrm{S}$ Lat, $73^{\circ} 39^{\prime} 50^{\prime \prime} \mathrm{W}$ Long). Coll. 1965 and subm. 
by G. S. Vescelius. Comment: should date the pre-ultimate phase of occupation at Puyenca II, ca. A.D. 1525 according to ceramics.

\section{Hv-1085. El Gentilar, Peru}

$670 \pm 70$

Textile fragments from Stratum X (Level J) of midden below surface, at El Gentilar ( $17^{\circ} 41^{\prime} 45^{\prime \prime} \mathrm{S}$ Lat, $71^{\circ} 22^{\prime} 15^{\prime \prime} \mathrm{W}$ Long). Coll. 1965 and subm. by G. S. Vescelius. Comment: should date earliest phase of culture sequence at El Gentilar, estimated age A.D. 1150.

\section{Hv-1151. Totimelmacau, Mexico}

$2150 \pm 125$

200 B.c.

Charcoal from excavation, $1.8 \mathrm{~m}$ depth, near Totimelmacau on uplands of Puebla ( $18^{\circ} 54^{\prime} \mathrm{N}$ Lat, $98^{\circ} 11^{\prime} \mathrm{W}$ Long), imbedded in calcareous bituminous layers. Coll. 1965 and subm. by Bodo Spranz, Museum für Völkerkunde, Freiburg, Württemberg. Comment: from pre-classic pyramid, age between 600 B.C. and A.D. 300 was assumed (Piña Chan, 1958).

\section{WATER SAMPLES}

\section{Arnold series, Nordrhein-Westfalen}

Fixed and free carbonic acid, precipitated from water of several lysimeters at Arnold (52॰ 13' 8" N Lat, $7^{\circ} 22^{\prime} 47^{\prime \prime}$ E Long). Coll. June 1965 and subm. by Heinrich Fauth, B.f.B.

\section{Hv-1015. Heath lysimeter}

$100.7 \pm 1.4 \%$ modern

Stale water sample from lysimeter filled with calcareous sand and gravel, which is overgrown by heath. $\delta \mathrm{C}^{13}=-21.7 \%$; $\delta \mathrm{C}_{\mathrm{MI}}{ }^{13}=-17.8 \%$.

Hv-1016. Deciduous-forest lysimeter $\quad 90.4 \pm \mathbf{2 . 2} \%$ modern

Stale water sample from lysimeter filled with gravelly calcareous sand and overgrown by deciduous forest. $\delta \mathrm{C}^{13}=-18.0 \%$; $\delta \mathrm{C}_{\mathrm{MN}}{ }^{13}=$ $-14.4 \%$.

\section{Hv-1017. Deciduous-forest lysimeter $\quad 89.1 \pm 1.8 \%$ modern}

Directly extracted water sample from same lysimeter as $\mathrm{Hv}-1016$. $\delta \mathrm{C}^{13}=-18.2 \% ; \delta \mathrm{C}_{\mathrm{MI}}{ }^{13}=-14.0 \%$.

\section{Hv-1018. Coniferous-forest lysimeter $91.5 \pm 4.2 \%$ modern}

Stale water sample taken from lysimeter filled with calcareous sand and overgrown by coniferous forest. $\delta \mathrm{C}^{13}=-18.3 \% ; \delta \mathrm{C}_{\mathrm{MI}}{ }^{13}=-14.4 \%$. Comment: $\mathrm{C}^{14}$ activity of recent waters exceeds that found earlier (Münnich, 1957), owing to atom bomb-tests. Higher activity of $\mathrm{Hv}-10 \mathrm{I} 5$ may have been produced by larger pore volume in the extraction lysimeter (Wendt and others, 1967). It is remarkable that the computed $\delta \mathrm{C}_{\mathbf{M}}{ }^{13}$ values exceed the measured ones. 


\section{Valley of Elbe river series, Norddeutschland}

Fixed and free carbonic acid, precipitated by $\mathrm{Ba}(\mathrm{OH})_{2}$ from water taken from some deep and some shallow groundwater near valley of Elbe river. Coll. 1964 and subm. by H. Fauth.

Hv-681. Schutschur, 5.5 to $10.5 \mathrm{~m} \quad 56.2 \pm 1.1 \%$ modern Water from lst aquifer below surface $\left(53^{\circ} 13^{\prime} 6^{\prime \prime} \mathrm{N}\right.$ Lat, $10^{\circ} 55^{\prime} 42^{\prime \prime}$ E Long). $\delta \mathrm{C}^{13}=-10.7 \%$; $\delta \mathrm{C}_{\mathbf{M}^{13}}{ }^{13}=-13.1 \%$; apparent age $3325 \mathrm{yr}$.

\section{Hv-684. Elstorf, 34 to $42 \mathrm{~m}$}

$54.6 \pm 0.9 \%$ modern

Water from 2nd aquifer below surface $\left(53^{\circ} 25^{\prime} 24^{\prime \prime} \mathrm{N}\right.$ Lat, $9^{\circ} 46^{\prime}$ $44^{\prime \prime}$ E Long). $\delta \mathrm{C}^{13}=-13.2 \% ; \delta \mathrm{C}_{\mathrm{MI}^{13}}=-15.3 \%$; apparent age $3555 \mathrm{yr}$.

\section{Hv-685. Sinstorf, 42 to $54 \mathrm{~m}$}

$55.2 \pm 0.8 \%$ modern

Water from 2nd aquifer below surface (53 $25^{\prime} 32^{\prime \prime} \mathrm{N}$ Lat, $9^{\circ} 57^{\prime} 24^{\prime \prime}$ E Long). $\delta \mathrm{C}^{13}=-15.8 \% ; \delta \mathrm{C}_{\mathbf{M}}{ }^{13}=-15.8 \%$; apparent age $3615 \mathrm{yr}$.

Hv-506. Niedermarschacht, 65 to $77 \mathrm{~m} \quad 43.5 \pm 0.9 \%$ modern

Water from 4 th aquifer below surface $\left(53^{\circ} 25^{\prime} 8^{\prime \prime} \mathrm{N}\right.$ Lat, $10^{\circ} 21^{\prime} 46^{\prime \prime}$ E Long). $\delta \mathrm{C}^{13}=-10.9 \%$; $\delta \mathrm{C}_{\mathrm{M}}{ }^{13}=-14.0 \%$; apparent age $5380 \mathrm{yr}$.

\section{Hv-682. Ashausen, 59 to $89 \mathrm{~m}$}

$42.5 \pm 1.0 \%$ modern

Artesian water from 3rd aquifer below surface $\left(53^{\circ} 21^{\prime} 54^{\prime \prime} \mathrm{N}\right.$ Lat, $10^{\circ} 9^{\prime} 6^{\prime \prime} \mathrm{E}$ Long). $\delta \mathrm{C}^{13}=-15.3 \% ; \delta \mathrm{C}_{\mathrm{M}^{13}}=-13.9 \%$; apparent age 5570 yr. Comment: plotting of apparent ages of these samples against depth of extraction shows strong linear dependence. Slope of relationship is steeper than that of the sealevel curve, so filling of aquifers seems unconnected to sealevel rise nor does theory of age distribution of groundwater in open aquifers (Vogel, 1965) provide satisfactory explanation. The calculated $\delta \mathrm{C}^{13}$ values correspond to measured ones within limits of error, proving that no biogenic $\mathrm{CO}_{2}$ has entered the system.

\section{Niedersachsen series, Norddeutschland}

Fixed and free carbonic acid from water samples, precipitated by $\mathrm{Ba}(\mathrm{OH})_{2}$ from some deep and some shallow ground-waters in N Germany. Coll. 1965 and subm. by Heinrich Fauth.

Hv-1180. Wittingen, 108 to $120 \mathrm{~m} \quad 14.8 \pm 1.4 \%$ modern

Water from 3rd aquifer below surface $\left(52^{\circ} 42^{\prime} 52^{\prime \prime} \mathrm{N}\right.$ Lat, $10^{\circ} 43^{\prime}$ $36^{\prime \prime} \mathrm{E}$ Long). $\delta \mathrm{C}^{13}=-11.5 \% ; \delta \mathrm{C}_{\mathbf{M}}{ }^{13}=-13.0 \%$; apparent age $14,050 \mathrm{yr}$.

Hv-1171. Schwarmstedt, 10 to $18 \mathrm{~m} \quad \mathbf{7 4 . 3} \pm \mathbf{3 . 1} \%$ modern Sample from 2nd aquifer below surface $\left(52^{\circ} 40^{\prime} 18^{\prime \prime} \mathrm{N}\right.$ Lat, $9^{\circ} 37^{\prime}$ $12^{\prime \prime} \mathrm{E}$ Long). $\delta \mathrm{C}^{13}=-17.7 \% ; \delta \mathrm{C}_{\mathbf{M}}{ }^{13}=-20.4 \%$; apparent age $1080 \mathrm{yr}$. 
Hv-1122. Lüneburg, 98 to $126 \mathrm{~m}$

$54.9 \pm 1.2 \%$ modern

Water from 4th aquifer below surface $\left(53^{\circ} 16^{\prime} 31^{\prime \prime} \mathrm{N}\right.$ Lat, $10^{\circ} 24^{\prime} 7^{\prime \prime}$ E Long). $\delta \mathrm{C}^{13}=-12.2 \%$; $\delta \mathrm{C}_{\mathrm{MI}^{13}}=-13.3 \%$; apparent age $3510 \mathrm{yr}$.

Hv-1013. Adendorf, 146 to $166 \mathrm{~m} \quad 50.3 \pm 1.1 \%$ modern

Sample from 4th aquifer below surface $\left(53^{\circ} 16^{\prime} 40^{\prime \prime} \mathrm{N}\right.$ Lat, $10^{\circ} 28^{\prime}$ 00 " $\mathrm{E}$ Long). $\delta \mathrm{C}^{13}=-10.5 \%$; $\delta \mathrm{C}_{\mathbf{M}}{ }^{13}=-13.0 \%$; apparent age $4215 \mathrm{yr}$.

Hv-1186. Eckerde, 8 to $18 \mathrm{~m}$

$61.0 \pm 1.3 \%$ modern

Water from 2nd aquifer below surface $\left(52^{\circ} 19^{\prime} 60^{\prime \prime} \mathrm{N}\right.$ Lat, $9^{\circ} 31^{\prime}$ $36^{\prime \prime} \mathrm{E}$ Long). $\delta \mathrm{C}^{13}=-11.0 \%$; $\delta \mathrm{C}_{\mathrm{M}^{13}}=-13.4 \%$; apparent age $2660 \mathrm{yr}$.

Hv-1010. Elstorf, 34 to $42 \mathrm{~m}$

$53.4 \pm 0.7 \%$ modern

Sample from 2nd aquifer below surface $\left(53^{\circ} 25^{\prime} 58^{\prime \prime} \mathrm{N}\right.$ Lat, $10^{\circ} 3^{\prime}$ $24^{\prime \prime} \mathrm{E}$ Long). $\delta \mathrm{C}^{13}=-13.2 \%$; $\delta \mathrm{C}_{\mathrm{M}^{13}}=-16.1 \%$; apparent age $3735 \mathrm{yr}$.

Hv-996. Nordhorn, 19 to $44 \mathrm{~m}$

$39.1 \pm 0.9 \%$ modern

Water from 2nd aquifer below surface $\left(52^{\circ} 25^{\prime} 32^{\prime \prime} \mathrm{N}\right.$ Lat, $7^{\circ} 4^{\prime} 25^{\prime \prime}$ E Long). $\delta \mathrm{C}^{13}=-11.7 \%$; $\delta \mathrm{C}_{\mathrm{M}^{13}}=-14.6 \%$; apparent age $6240 \mathrm{yr}$.

Hv-730. Soltau, 32 to $42 \mathrm{~m}$

$69.6 \pm 1.5 \%$ modern

Sample from lst aquifer below surface $\left(52^{\circ} 59^{\prime} 22^{\prime \prime} \mathrm{N}\right.$ Lat, $9 \circ 51^{\prime}$ 12 " $\mathrm{E}$ Long). $\delta \mathrm{C}^{13}=-18.7 \%$; $\delta \mathrm{C}_{\mathbf{M}^{13}}=-19.8 \%$; apparent age $1600 \mathrm{yr}$.

Hv-729. Tüitsberg, 42 to $49 \mathrm{~m}$

$76.1 \pm 1.7 \%$ modern

Sample from 4th aquifer below surface $\left(53^{\circ} 6^{\prime} 55^{\prime \prime} \mathrm{N}\right.$ Lat, $9^{\circ} 54^{\prime} 54^{\prime \prime}$ E Long). $\delta \mathrm{C}^{13}=-22.1 \%$; $\delta \mathrm{C}_{\mathbf{M}^{13}}=-22.1 \%$; apparent age 890 yr. Comment: in most cases, the $\mathrm{C}^{14}$ values were confirmed on remeasurment. Of interest is the age of sample $\mathrm{Hv}-1180$ of more than 12,000 yr. Even if $\mathrm{C}^{14}$ activity of recent water is very much lower than assumed $(85 \%$ of NBS standard), calculated age is still older than postglacial. Contribution of biogenic $\mathrm{CO}_{2}$ seems ruled out by high $\delta \mathrm{C}^{13}$ values.

\section{West-Niedersachsen series, Norddeutschland}

Fixed and free carbonic acid, precipitated by $\mathrm{Ba}(\mathrm{OH})_{2}$ from some deep and some shallow groundwaters, lying in sandy and gravelly layers. Coll. 1965 and subm. by Heinrich Fauth.

Hv-1004. Aurich, 67 to $82 \mathrm{~m}$

$76.8 \pm 1.3 \%$ modern

Water from 2nd aquifer below surface (5328 $53^{\prime \prime} \mathrm{N}$ Lat, $7^{\circ} 29^{\prime} 24^{\prime \prime}$ E Long). $\delta \mathrm{C}^{13}=+3.2 \%$; $\delta \mathrm{C}_{\mathbf{M}^{13}}{ }^{13}=-21.7 \%$; apparent age $820 \mathrm{yr}$.

Hv-1003. Marienhafe, 37 to $64 \mathrm{~m}$

$54.9 \pm 0.9 \%$ modern

Mixed water from 2nd and 3rd aquifer from waterwork $\left(53^{\circ} 29^{\prime}\right.$ $55^{\prime \prime} \mathrm{N}$ Lat, $7^{\circ} 17^{\prime} 17^{\prime \prime} \mathrm{E}$ Long). $\delta \mathrm{C}^{13}=+4.6 \% ; \delta \mathrm{C}_{\mathrm{MI}}{ }^{13}=-16.8 \%$; apparent age $3510 \mathrm{yr}$. 
Hv-1007. Zwischenahn, 15 to $34 \mathrm{~m} \quad 59.2 \pm 1.8 \%$ modern

Water from 2nd aquifer below surface $\left(53^{\circ} 11^{\prime} 12^{\prime \prime} \mathrm{N}\right.$ Lat, $8^{\circ} 2^{\prime} 6^{\prime \prime}$ E Long). $\delta \mathrm{C}^{13}=-8.3 \%$; $\delta \mathrm{C}_{\mathrm{M}^{13}}=-16.3 \%$; apparent age $2910 \mathrm{yr}$.

\section{Hv-1008. Westrhauderfeen, 44 to $45 \mathrm{~m}$}

$$
70.3 \pm 0.9 \% \text { modern }
$$

Water from 2nd aquifer below surface $\left(53^{\circ} 8^{\prime} 39^{\prime \prime} \mathrm{N}\right.$ Lat, $7^{\circ} 32^{\prime} 27^{\prime \prime}$ E Long). $\delta \mathrm{C}^{13}=+5.9 \%$; $\delta \mathrm{C}_{\mathrm{M}^{13}}=-22.1 \%$; apparent age $1525 \mathrm{yr}$. Sample from same place as $\mathrm{Hv}-385$ (Hannover III).

Hv-1006. Westerstede, 43 to $60 \mathrm{~m} \quad 62.3 \pm 1.1 \%$ modern

Mixed water from 2nd and 3rd aquifer below surface (53 $16^{\prime} 28^{\prime \prime}$ $\mathrm{N}$ Lat, $7^{\circ} 58^{\prime} 15^{\prime \prime} \mathrm{E}$ Long). $\delta \mathrm{C}^{13}=-9.7 \%$; $\delta \mathrm{C}_{\mathrm{NI}}{ }^{13}=-15.1 \%$; apparent age $2490 \mathrm{yr}$.

\section{Hv-997. Wietmarschen, 29 to $37 \mathrm{~m} \quad 52.5 \pm 0.7 \%$ modern}

Water from 3rd aquifer below surface $\left(52^{\circ} 33^{\prime} 39^{\prime \prime} \mathrm{N}\right.$ Lat, $7^{\circ} 6^{\prime} 56^{\prime \prime}$ E Long). $\delta \mathrm{C}^{13}=-5.6 \% ; \delta \mathrm{C}_{\mathrm{M}^{13}}=-14.8 \%$; apparent age $3870 \mathrm{yr}$.

\section{Hv-995. Veldhausen, 69 to $79 \mathrm{~m} \quad 48.1 \pm 0.7 \%$ modern}

Water from 4th aquifer below surface $\left(52^{\circ} 35^{\prime} 54^{\prime \prime} \mathrm{N}\right.$ Lat, $6^{\circ} 51^{\prime} 44^{\prime \prime}$ E Long). $\delta \mathrm{C}^{13}=-8.3 \% ; \delta \mathrm{C}_{\mathrm{M}^{13}}=-15.3 \%$; apparent age $4575 \mathrm{yr}$.

\section{Hv-999. Neermoor, 20 to $66 \mathrm{~m} \quad 57.1 \pm 0.8 \%$ modern}

Mixed water from 2nd and 3rd aquifer below surface $\left(53^{\circ} 20^{\prime} 26^{\prime \prime}\right.$ $\mathrm{N}$ Lat, $7^{\circ} 22^{\prime} 35^{\prime \prime}$ E Long). $\delta \mathrm{C}^{13}=-4.2 \% ; \delta \mathrm{C}_{\mathrm{MN}}{ }^{13}=-16.9 \%$; apparent age 3200 yr. Comment: the upper layers down to $1 \mathrm{~m}$ depth contain a large quantity of humous peat. This fact renders the application of the simple model for water age determination (Münnich, 1957; Münnich and Vogel, 1959) impossible, for the apparent ages will certainly be wrong. The deviations of the $\delta \mathrm{C}_{\mathrm{M}^{13}}$ from the measured $\delta \mathrm{C}^{13}$ values confirm the participation of $\mathrm{CO}_{2}$-produced by humic acid from limestonein the carbonic acid-water-chemistry (Vogel and Ehhalt, 1963; Geyh, 1965b).

\section{CALCAREOUS SINTER}

\section{Spilkerhalle series, Niedersachsen}

Recent calcite samples from Langenfeld cave, situated in Malm fm. of Jurassic age $\left(52^{\circ} 12^{\prime} \mathrm{N}\right.$ Lat, $9^{\circ} 18^{\prime} \mathrm{E}$ Long). Coll. 1965 and subm. by Bodo Schillat, Hamburg.

Hv-1036. Spilkerhalle $89.6 \pm 1.6 \%$ modern

Recent sinter tubes of young stalactites; $\delta \mathrm{C}^{13}=-7.6 \%$.

Hv-1038. Spilkerhalle

$93.7 \pm 1.4 \%$ modern

Recent sinter leaf from a sinter basin; $\delta \mathrm{C}^{13}=-7.1 \%$. Comment: $\mathrm{C}^{14}$ activity of recent sinter from an active sinter basin exceeds values 
established earlier (Franke and others, 1959). It is probably wrong to consider natural exchange effects to be responsible for this, because water samples taken from lysimeters also show an increase of $\mathrm{C}^{14}$ activity ( $\mathrm{Hv}$ 1015 to $\mathrm{Hv}-1018$ ) due to atom bomb tests.

\section{Langenfeld I series, Niedersachsen}

Calcite samples from broken stalagmites of Langenfeld cave $\left(52^{\circ}\right.$ $12^{\prime} \mathrm{N}$ Lat, $9^{\circ} 18^{\prime} \mathrm{E}$ Long), situated in the Malm fm. of Jurassic age (Schillat, 1959). The samples are to delineate the period where intensive sinter growth was possible.

\section{Hv-1071. Atlantishalle}

$35.2 \pm 1.9 \%$ modern

Regenerated sinter layer above first break-off of a stalagmite; $\delta \mathrm{C}^{13}$ $=-2.4 \%$; apparent age $7080 \mathrm{yr}$.

\section{Hv-1073. Atlantishalle}

$51.8 \pm 1.7 \%$ modern

Regenerated sinter layer above second break-off of the regenerated stalagmite, from the same object as $\mathrm{Hv}-1071 ; \delta \mathrm{C}^{13}=-5.6 \%$; apparent age $4000 \mathrm{yr}$.

\section{Hv-1074. Spilkerhalle}

$56.3 \pm 1.1 \%$ modern

Regenerated sinter layer above break-off of a stalagmite; $\delta \mathrm{C}^{13}=$ $-5.0 \%$ apparent age $3310 \mathrm{vr}$.

Hv-1063. Sinter basin

$53.4 \pm 1.1 \%$ modern

Calcite cap of a stalagmite in an old sinter basin without water; $\delta \mathrm{C}^{13}=-8.0 \%$; apparent age $3740 \mathrm{yr}$.

\section{Hv-1066. Sinter basin}

$54.0 \pm 1.1 \%$ modern

Chalky base zone of a stalagmite, from same object as $\mathrm{Hv}-1063$. Sample was corroded by water in earlier times. $\delta \mathrm{C}^{13}=-8.0 \%$; apparent age $3660 \mathrm{yr}$. Comment: age of $\mathrm{Hv}-107 \mathrm{l}$ fixes beginning of the period of intensive sinter growth. After an abnormally strong growth of $4 \mathrm{~mm} / 100$ $\mathrm{yr}$, the regeneration of stalagmites ended ca. 4000 to 3300 B.P. (Hv-1073, Hv-1074, Hv-1063 and Hv-1066); (Geyh and Schillat, 1966).

\section{Langenfeld II series, Niedersachsen}

Calcite from stalagmite fragments of Langenfeld cave $\left(52^{\circ} 12^{\prime} \mathrm{N}\right.$ Lat, $9^{\circ} 18^{\prime}$ E Long), situated in the Malm fm. of Jurassic age. Coll. 1965 and subm. by B. Schillat. Samples date periods of growth of calo-sinter and serve to check the model of calc-sinter dating (Franke and others, 1959; Franke, 1951).

Hv-1029. Langenfeld $4.8 \pm 1.6 \%$ modern

Calcite from stalagmite, 0 to $1 \mathrm{~cm}$ below surface; $\delta \mathrm{C}^{13}=-6.0 \%$; apparent age 23,000 yr. 
Hv-1030. Langenfeld

$4.1 \pm 1.5 \%$ modern

Calcite from same stalagmite as $\mathrm{Hv}-1029,1$ to $2 \mathrm{~cm}$ below surface; $\delta \mathrm{C}^{13}=-5.4 \%$; apparent age $24,350 \mathrm{yr}$.

\section{Hv-1033. Langenfeld}

$<1.4 \%$ modern

Calcite from same stalagmite as $\mathrm{Hv}-1029,4$ to $5 \mathrm{~cm}$ below surface; $\delta \mathrm{C}^{13}=+1.0 \%$; apparent age $>33,000 \mathrm{yr}$.

\section{Hv-1035. Langenfeld}

$<1.5 \%$ modern

Calcite from same stalagmite as $\mathrm{Hv}-1029,6$ to $7 \mathrm{~cm}$ below surface; $\delta \mathrm{C}^{13}=-10.1 \%$; apparent age $>32,600 \mathrm{yr}$.

\section{Hv-1028. Biwakhalle}

$5.5 \pm 1.5 \%$ modern

Calcite from regenerated cap of broken-off stalagmite (No. 3$) ; \delta \mathrm{C}^{13}$ $=-5.0 \%$; apparent age 22,000 $\mathrm{yr}$.

\section{Hv-1068. Atlantishalle}

$1.9 \pm 0.8 \%$ modern

Calcite from regenerated cap of broken-off stalagmite (No. 20); $\delta \mathrm{C}^{13}=-0.1 \%$; apparent age $30,350 \mathrm{yr}$.

\section{Hv-1069. Atlantishalle}

$20.4 \pm 1.2 \%$ modern

Calcite from regenerated cap of broken-off stalagmite (No. 16); $\delta \mathrm{C}^{13}=-1.7 \%$; apparent age $11,500 \mathrm{yr}$.

\section{Hv-1075. Spilkerhalle}

$2.7 \pm 0.8 \%$ modern

Calcite from regenerated cap of broken-off stalagmite (No. 10); $\delta \mathrm{C}^{1.3}=-4.6 \%$; apparent age 27,700 yr. Comment: assuming correctness of calculated apparent age sinter grew also during interstadials and interglacials. The $\delta \mathrm{C}^{13}$ values were commonly found to be lower in cold periods than in warm periods. To explain this result simply by temperature dependence of isotopic fractionation during lime precipitation is not possible. Other isotopic exchange processes must play a part as well (Geyh and Schillat, 1966).

\section{NATURAL CONTAMINATED SAMPLES}

\section{Hv-801. Hohes Holz, Niedersachsen $218.0 \pm 2.8 \%$ modern}

Fixed and free carbonic acid precipitated by $\mathrm{Ba}(\mathrm{OH})_{2}$ from water of 2nd aquifer in 30 to $60 \mathrm{~m}$ depth below surface near Wunstorf $\left(52^{\circ} 26^{\prime}\right.$ 33" N Lat, 9० 23' 12" E Long). Coll. and subm. by Heinrich Fauth. $\delta \mathrm{C}^{13}=-12.1 \%$. Comment: the extreme $\mathrm{C}^{14}$ activity cannot be explained. Laboratory contamination can be excluded.

\section{Hv-639. Schalchen, Bayern}

$175.3 \pm 1.4 \%$ modern

Unpreserved mammoth bone, depth 4.0 to $6.0 \mathrm{~m}$, near Schalchen (47 $53^{\prime} 44^{\prime \prime} \mathrm{N}$ Lat, $12^{\circ} 25^{\prime} 48^{\prime \prime} \mathrm{E}$ Long), overlain by sand and limestone gravel above groundwater level. Coll. 1938 and subm. by Ortwin Ganss, 
G. L. Bayern, München. Comment: date expected to correlate with "overthrust moraines" (Ganss, 1953) from the Würm glacial. The preparation of counting gas was made by combustion. Laboratory contamination can be excluded.

\section{Hv-1104. Hannover, Niedersachsen}

$179.8 \pm 3.7 \%$ modern

$\mathrm{CO}_{2}$ from air, precipitated by bubbling through $\mathrm{Ba}(\mathrm{OH})_{2}$ during a

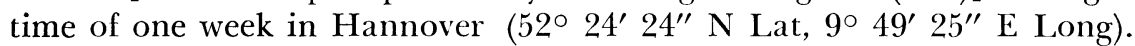
Coll. June 1965 and subm. by Heinrich Fauth. Comment: increase of $\mathrm{C}^{14}$ activity of carbon dioxide due to atom bomb tests corresponds to values measured elsewhere (Nydal, 1964).

Date lists:

\section{RFFFRFNCFS}

$\begin{array}{ll}\text { Hannover I } & \text { Wendt, Schneekloth, and Budde, 1962 } \\ \text { Hannover II } & \text { Geyh, Schncekloth, and Wendt, 1962 } \\ \text { Hannover III } & \text { Geyh and Schneckloth, 1964 }\end{array}$

Behrens, H., 1962, ${ }^{14} \mathrm{C}$-Daten für mitteldeutsches Neolithikum: Jahresschr. mitteldtsche Vorgeschichte, v. 46 , p. 41.

Bennett, W. C., 1946, The Atacameno: Handbook South Am. Indians, v. 2, p. 599.

Bird, J. B., 1946, The cultural sequence of the North Chilean coast: Handbook South Am. Indians, v. 2, p. 587.

Deichmüller, J., 1965a, Rössener Stilvariante am Dümmer: Fundchronik des Landes Niedersachsen und Land Bremen: Germania, v. 43, II, p. 334. 1965b, Die neolithische Moorsiedlung Hüde I am Dümmer, Krs. Grafschaft Dicpholz: Neue Ausgrabungen und Funde in Niedersachsen, v. 2, p. 1.

Franke, H. W., 1951, Altersbestimmungen an Sinter mit radioaktivem Kohlenstoff: Höhle, v. 2, p. 62.

Franke, H. W., Münnich, K. O., and Vogel, J., 1959, Erste Ergebnisse von KohlenstoffIsotopenmessungen an Kalksintern: Höhle, v. 10, p. 17.

Ganss, O., 1953, Neue Beobachtungen aus würmzeitlichen Chiemsee-Gletschern: Geologica Baverica, v. 19, p. 94.

Geyh, M. A., 1965a, Proportional counter equipment for sample dating with ages exceeding 60,000 years в.P. without enrichment: Internat. Conf. Radiocarbon and Tritium Dating, 6th, Pullman. Washington, Proc., p. 29.

1965b, The Hannover present and future hydrology program: Working Group on Isotopes in Hydrology, Grenoble, October 1965, ST 1 /REP/104, IAEA Wien, 1966, p. 56.

1966, Betrachtungen ïber ${ }^{14} \mathrm{C}$-Gemischtprobendatierungen: Zeitschr. f. Geophysik, v. 32, p. 154.

Geyh, M. A. and Wendt, I., 1965, Results of water sample dating by means of the model of Münnich and Vogel: Internat. Conf. Radiocarbon and Tritium Dating, 6th, Pullman, Washington, Proc., p. 597.

Geyh, M. A. and Schillat, B., 1966, Messungen der Kohlenstoffisotopenhäufigkeit von Kalksinterproben aus der Langenfelder Höhle: Aufschluss, v. 17, p. 315.

Göttlich, K. H., 1965, Der vorgeschichtliche Damm von Moosburg zum "Insele" im Seelenhofer Ried: Jh. Ver. Vaterl. Naturkunde, Württemberg, v. 120, p. 217.

Heinz, R., 1933, Ein vorzeitlicher Tränkplatz in der Nambiwüste bei Lüderitzbucht (Deutsch-Südwestrafrika): Mitt. Geog. Gesell. in Hamburg, v. 43, p. 267.

Henneböle, E., 1959, Brandbestattungen im Nettelstädter Forst: Heimatblätter, v. 45 , Folge 15, p. 57.

Hentger, N., 1962, Das Stift Möllenbeck an der Weser: Hildesheim.

Houtermans, F. G. and Oeschger, H., 1958, Proportional-Zählrohr zur Messung schwacher Aktivität weicher $\beta$-Strahlung: Helv. Phys. Acta, v. 31, p. 117. 
Kı̈̈ll, H., 1959, Die nordwestdeutsche Tiefstichkeramik und ihre Stellung im nordund mitteleuropäischen Neolithikum: Münster.

Krusch, B., 1933, Die Übertragung des H1. Alexander durch den Enkel Widekinds: Nachr. Ges. Wiss. zu Göttingen, Phil.-Hist. K1., p. 405.

Lang, H. D., 1962, Die Eisenerzvorkommen von Isernhagen bei Hannover: Naturhist. Gesell., v. 106, p. 19.

Maier, K., 1966, Neue Fragen zur Frühgeschichte der Kirche Möllenbeck an der Weser: Zeitschr. für Heimat und Kultur, v. 66, p. 21.

1964, Bericht über die Voruntersuchung einer bronzezeitlichen Siedlung an der Walkemïhle zu Göttingen in den Jahren 1963 und 1964: Göttinger Jahrb., v. 12, p. 19.

Maier, R. and Peters, H. G., 1965, Urgeschichtliche Siedlungsreste in Rosdorf, Kreis Gö̈ttingen: Neuc Ausgrabungen und Forschungen in Niedersachsen, v. 2, p. 19

Mever, B., Münnich, K. O., and Willerding, U., 1963, ${ }^{14} \mathrm{C}-$ Daten zur prähistorischen Besiedelung des Leinetalgrabens bei Göttingen: Göttinger Jahrb. v. 11, p. 5.

Münnich, K. O., 1957, Messungen des ${ }^{14} \mathrm{C}-$ Gehaltes von harten Grundwässern: Naturwissenschaften, v. 44 , p. 32.

Mümnich, K. O. and Vogel, J., 1959, "'C-Altersbestimmung von Grundwasser: Naturwissenschaften, v. 46, p. 10.

Nydal, R., 1964, Radioaktivt Carbon-14 fra kjernefysiske eksplosjoner: Fra fysikkens Verden, v. 23, p. 51

Pearson Jr., F. J., 1965, Use of $\mathrm{C}^{13} / \mathrm{C}^{12}$ ratios to correct radiocarbon ages of material, initially diluted by limestone: Internat. Conf. Radiocarbon and Tritium Dating, 6th, Pullman, Washington, Proc., p. 357.

Peters, H. G., 1965, Untersuchung an vor- und frühgeschichtlichen Wallanlagen am Rande des Göttinger Leinetal-Beckens: Germania, v. 43, II, p. 408.

Piña Chan, R., 1958, Excavaciones arqueologicas en Tlatilco: Tlatilco, v. 1, p. 119

Schillat, B., 1959, In den Höhlen des Weserberglandes: Aufschlusz, v. 10, p. 29.

Schüncmam, D. 1965, Zwei Grabhügel der Einzelgrabkultur in Luttum, Krs. Verden: Nachr. aus Niedersachsens Urgeschichte-Fundchronik, v. 34, p. 76.

Vogel, I., 1965, Age distribution of ground water in an open aquifer: Working Group on Isotopes in Hydrology, Grenoble Oct. 1965, ST1/REP/104, IAEA Wien 1966, p. 52.

Vogel, I and Ehhalt, D., 1963, The use of the carbon isotopes in ground water studies: Radioisotopes in Hydrology, IAEA Vienna, p. 383.

De Vrics, Hl., stuiver, M., and Olsson, I., 1959, A proportional counter for lowlevcl-counting with high efficiency: Nuclear Instruments and Methods, v. 5, p. 111.

Wendt, I., Stahl, W., Geyh, M. A., and Fauth, H., 1967, Model experiments for "C-water age determinations: Symposium on the Use of Isotopes in Hydrology, Nov. 1966, Wien, SM-82/22, Proc. 